\title{
JUHÁSZ JÚLIA
}

\section{Büntetés-végrehajtási pártfogó felügyelői tevékenység a munkaerőpiaci integráció tükrében}

Az egyének munkaerőpiaci helyzete köztudottan befolyásoló tényező a bünözési mutatók, illetve a visszaesés alakulásában, önmagában azonban a kedvezőtlen munkaerőpiaci helyzetre nem tekinthetünk önálló oksági viszonyként a büncselekmény elkövetése vagy a visszaesés gyakoriságának vizsgálatakor. Az ELTE kriminológiai tanszéke már az 1980-as években végzett kutatást a hátrányos társadalmi helyzet és a bünözés összefüggéseinek kapcsán, ebből egyértelmüen fény derült arra, hogy a halmozottan hátrányos helyzet és a bünözés között szoros kapcsolat áll fenn. A vizsgált faktorok körében szerepelt egyebek között az alacsony iskolai végzettség, az alacsony jövedelem, a szakképzettség hiánya, a szenvedélybetegségek stb. ${ }^{1}$ E kutatás is igazolta - természetesen nem kizárólagos okként - a munkaerőpiaci státus kiemelt szerepét a büncselekmények elkövetésének vonatkozásában. Mivel a munkaerőpiaci státus jellegét nagyban befolyásolja az iskolai végzettség, a szakképzettség megléte/hiánya - a jövedelem pedig okozatként jelenik meg -, szükséges a negatív rizikófaktorok csökkentése, hogy a bünözés útjára lépöket sikeresen reintegrálhassuk a társadalomba.

A tanulmányban a büntetés-végrehajtási pártfogó felügyelők (a továbbiakban: bv. pártfogó) tevékenységével összefüggő, munkaerőpiaci integráció fókuszú bünismétlés-megelózési módszerek hazai bemutatására kerül sor, amely a gyakorlati munkában megjelenő problémákra is reagál, továbbá javaslatok megfogalmazására kerül sor, amelyek megvalósulása esetén a szabadultak reintegrációjában pozitív változás várható.

1 Vigh József: Bűnismétlők, visszaesők, veszélyes bűnözők. In: Gönczöl Katalin - Korinek László Lévai Miklós (szerk.): Kriminológiai ismeretek - Bünözés - Bünözéskontroll. Corvina Kiadó, Budapest, 1999, 243-252. o. 


\section{A munkaerőpiaci integráció szerepe a bünismétlési kockázatok csökkentésében}

A büntetés-végrehajtás törekvései

A reintegrációs eszközök között mind az európai, mind a magyar büntetésvégrehajtási jogi szabályozásban a munkáltatásé a központi szerep. A büntetés-végrehajtásnak arra kell törekednie, hogy a fogvatartottakat elegendő és hasznos munkával lássa el. „Hasznosnak az a munka tekinthetö, amely fejleszti, vagy legalábbis szinten tartja a fogvatartott azon fizikai és szellemi képességeit, amelyek segitségével a szabadulás után érvényesülhet a munkaeröpiacon."

Az előzőekben vázolt irányt a fogvatartotti, illetve a szabadult populáció is megerősíti, Albert és Biró ${ }^{3}$ az általuk végzett utánkövetéses vizsgálat során megállapította, hogy a fogvatartottak szabadulásuk előtt és az után is rendkívül fontosnak tartják a munkavállalást. Éppen ezért a büntetés-végrehajtási intézetekben (a továbbiakban: bv. intézet) szabadságvesztés-büntetésüket töltők számára a foglalkoztatás - amely magában foglalja a munkáltatást, az oktatást és a szakmaképzést - a tervek szerint 2018. december 31-ig teljes körüvé válik. Az elérni kívánt cél a fogvatartottak „munkára nevelése”, de legalább anynyira fontos az olyan piacképes szakmához juttatás, amellyel a szabadulásuk után a való életben az elhelyezkedés és a megélhetés is biztosítottá válik.

A foglalkoztatás fogvatartotti viselkedésre való pozitív hatását $C$ sima ${ }^{4}$ statisztikai elemzések alapján mutatja be. A fogvatartottak körében a munkáltatásba, oktatásba bevontak számának növekedésével fordítottan arányos a fegyelmi eljárások száma, tehát minél többeket sikerül bevonni, annál kevesebb a fegyelemsértés.

A fogvatartottak bv. intézeten belüli munkáltatása több célt is szolgál: a fogvatartott részére a munkaszocializáció alapjait, annak folyamatos fenntartását, valamint a bv. szervezet részére a belső ellátási tevékenységet is meg-

\footnotetext{
2 Pallo József: Modernizációs csomópontok „,de lege ferenda” a magyar büntetés-végrehajtási jogban. Az Új utakon a magyar büntetés-végrehajtás címü, 2012. november 20-án megrendezett konferencián elhangzott előadás, 11. o. http://www.kriminalexpo.hu/hu/archiv/2012/szekcio+iv/kriminalexpo+2012++uj+utakon+a+magyar+buntetes-vegrehajtas+-+a+bvop+konferenciaja.html

3 Albert Fruzsina - Biró Emese: A sikeres reintegráció. In: Albert Fruzsina (szerk.): Életkeretek a börtönön innen és túl. Szubjektív reszocializációs esélyek. MTA Társadalomtudományi Kutatóközpont, Budapest, 2015, 143-165. o.

4 Csima Beáta: Reintegrációs tevékenység a büntetés-végrehajtásban. Hadtudományi Szemle, 2015/2., 225-232. o.
} 
oldja, ezen túl az úgynevezett külső bérmunkákkal a bv. intézet bevételeinek növelésében, így a költségek egy részének fedezésében is szerepet játszik. Meg kell említeni az elítéltek által önkéntesen végzett úgynevezett jóvátételi munkát is, amely fontos szerepet tölt be a fogvatartottak reintegrációjában, hiszen a résztvevők azt - felismerve a büncselekményük társadalomra való negatív kihatását - önkéntesen végzik.

1. számú kép

Az evangélikus parókia és templom takarítása Gyulán ${ }^{5}$

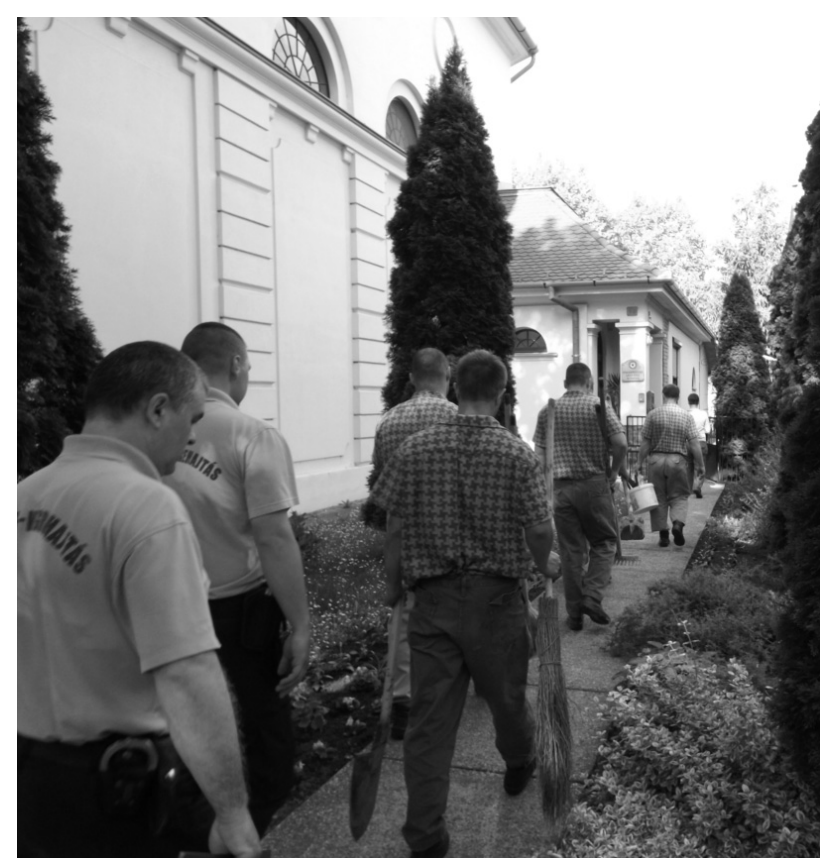

A foglalkoztatásra való kötelezettség mellett fontos kiemelni, hogy nem elég csupán végrehajtatni a szükséges tevékenységet. $S c h m e h l^{6}$ a munkáltatáson belül a büntetés-végrehajtás fö szerepének ,, a munka társadalmi szükségességének felismertetését és elfogadtatását, a szakmai ismeretek, munkatapasztalatok megszerzésének elösegitését” tartja. Ezek megvalósítása megalapozná az általuk végzett munka minőségének nagy mértékü javulását, mindamellett a munkára való motiváltság a szabadulás utáni életvitel kiala-

5 Fotó: Uhrin Ilona

6 Schmehl János: A neveléstől a reintegrációig: a fejlődés útja a legjobb gyakorlatok tükrében. Börtönügyi Szemle, 2015/1., 2. o. 
kításában is meghatározó szerepet játszhat. Juhász is megfogalmazta, hogy „a bv. intézeten belül a fogvatartottak piacképes szakmához juttatása, valamint a munkatapasztalatok megszerzése hatékonyan járulnak hozzá az elitéltek társadalmi reintegrációjához, amelyeket a bv. pártfogó felügyelök által végzett feladatok eredményesen kiegészitenek".

A következőkben sor kerül a bv. pártfogók által végzett ügykörök bemutatására annak érdekében, hogy az olvasó megismerhesse komplex munkatevékenységüket.

\section{A büntetés-végrehajtási pártfogó felügyelők tevékenységi körei}

„A büntetés-végrehajtási pártfogó felügyelö olyan hivatalos személy, aki a támogató és kontroll funkciók érvényesitésével végrehajtja a törvény alapján fennálló vagy elrendelt pártfogó felügyeletet, az igazságügyért felelös minisztérium, a törvényszék és a bv. szerv megkeresésére környezettanulmányt vagy pártfogó felügyelöi szakértöi véleményt készit a döntések megalapozásához, továbbá aktivan és hatékonyan részt vesz az elitéltek szabadulásra történö felkészitésében, valamint segitséget nyujjt a szabadult elitéltek részére a társadalomba való visszailleszkedésükben. Funkcióját tekintve bünmegelözési szakember, akinek legföbb célja a szabadulás elött álló és szabadult elítéltek eredményes reintegrációja, ezáltal a visszaesési kockázatuk csökkentése."

A bv. pártfogó jogszabály9 alapján tehát a következő tevékenységeket végzi:

- a feltételes szabadság tartamára törvény alapján fennálló vagy elrendelt pártfogó felügyelet végrehajtása;

- a feltételes szabadságra bocsátással összefüggésben elrendelt, valamint a külön magatartási szabály előírására vagy megváltoztatására irányuló pártfogó felügyelői vélemény készítése;

- a gondozás keretében végzett reintegrációs tevékenység;

- az utógondozás keretében végzett reintegrációs tevékenység;

- környezettanulmányok készítése;

7 Juhász Ferenc: A büntetés-végrehajtási pártfogó felügyelői tevékenység. Börtönügyi Szemle, 2015/2., 62. o.

8 Juhász Ferenc - Juhász Júlia - Nagy-Mitró Lilla - Somogyi Zsófia Borbála: A bünismétlés megelőzéséhez kapcsolódó büntetés-végrehajtási pártfogó felügyelői szakmai feladatok. Segédanyag. H. n., 2017, 7. o.

9 1995. évi CVII. törvény; 2013. évi CCXL. törvény; 8/2013. (VI. 29.) KIM rendelet; 16/2014. (XII. 19.) IM rendelet; $11 / 2014$. (XII. 13.) IM rendelet. 
- a feltételes szabadságra bocsátás lehetőségéből kizárt életfogytig tartó szabadságvesztésre ítéltek kötelező kegyelmi eljárása elbírálásához;

- a szabadságvesztés félbeszakítására irányuló kérelem indokoltságának ellenőrzése céljából;

- a reintegrációs őrizetbe helyezést megelözően;

- a fiatalkorú befogadó részlegbe helyezésekor;

- az elzárást, illetve szabadságvesztést töltő elítéltnek az adott ügyben előterjesztett kegyelmi kérelme esetében;

- a társadalmi kötődés programba történő behelyezés előtt, a kötelezően alkalmazandó eset kivételével.

Az előbbieken túl a bv. pártfogók tevékenysége kiterjed a reintegrációs örizetbe helyezett, és a társadalmikötődés-program jogintézménye alá bevont fogvatartottak segítő és kontrollfunkcióval megvalósított ellenőrzésére is.

A bv. pártfogók jelenlegi létszáma országosan 57. Az elöbbiekből kitünik, hogy feladataik sokrétüek és szerteágazók, amelyek jókora szervezőkészséget, precizitást, empátiát, kommunikációs készséget feltételeznek.

Jelen tanulmány leginkább a bv. intézeten belül végzett szabadulásra való felkészítés, illetve a pártfogó felügyelet végrehajtásának és az utógondozás jogintézményének részletesebb tárgyalását célozza meg, mivel a bv. pártfogó munkaeröpiaci integrációban betöltött szerepe e tevékenységi körökben jelenik meg legmarkánsabban.

\section{A bv. pártfogó munkaerôpiaci integrációval összefüggő feladatainak bemutatása}

Tekintettel arra, hogy a bv. pártfogó tevékenységei közül több is a szabadulás utáni munkába állást segíti elő, szükséges ezen ügykörök részletesebb bemutatása.

\section{Szabadulásra felkészités}

A bv. pártfogó a büntetések, az intézkedések, egyes kényszerintézkedések és a szabálysértési elzárás végrehajtásáról szóló 2013. évi CCXL. törvény (a továbbiakban: Bv. tv.) 185 . §-a, valamint a pártfogó felügyelői szolgálat tevékenységéról szóló 8/2013. évi KIM rendelet 62/E §-ában meghatározottak 
szerint végzi a szabadulásra felkészítés, vagyis a reintegrációs gondozási tevékenységet.

„A szabadulásra történö felkészités egyes elemeinek végrehajtása a reintegrációs tisztek hatáskörében maradt, ugyanakkor a tevékenység ellátása elsödlegesen a bv. pártfogók feladatává vált.

Annak részeként a bv. pártfogó:

- egyéni vagy csoportos tájékoztatást tart a reintegráció sikerességének elösegitése érdekében;

- értékeli a reintegrációs programban elért eredményeket, a reintegrációs programot szükség szerint kiegészíti, fejleszti;

- társadalmi-, munkaeröpiaci beilleszkedést célzó csoportos foglalkozásokat és tréningeket tart;

- felméri, hogy az elitélt rendelkezik-e befogadó környezettel, felveszi velük a kapcsolatot és együttmüködésük esetén felkésziti a hozzátartozókat az elitélt visszafogadására;

- szükség esetén segíti a családi kapcsolatok helyreállitását;

- gyógyintézetben, szociális intézményben való elhelyezés igénye esetén felveszi a kapcsolatot az ellátást nyújtó intézményekkel, indokolt esetben kezdeményezi az elitélt gondnokság alá helyezését;

- együttmüködik a helyi önkormányzatokkal, munkáltatókkal, segitö civil szervezetekkel, vallási közösségekkel, önkéntes közremüködökkel, az egyedi ügyekben koordinálja tevékenységüket." 10

A szabadulásra való felkészítés munkaerőpiaci vonatkozásában a bv. pártfogó személyes kapcsolatainak felhasználásán túl elsősorban a munkaügyi szervekre támaszkodhat. A Büntetés-végrehajtás Országos Parancsnoksága (BVOP) támogatásával 2016-ban minden bv. intézet együttmüködési megállapodást kötött a kormányhivatalok foglalkoztatási föosztályaival annak érdekében, hogy a szabadulás előtti információáramlást, valamint a pártfogoltak és utógondozottak munkába állását segítendő olyan konkrét kapcsolatokat alakíthasson ki a bv. pártfogó a foglalkoztatási főosztályok kirendeltségein dolgozókkal, amivel pozitív elmozdulás érhető el az álláskeresőként való regisztráció, a közfoglalkoztatásba való bevonás és a képzéseken való részvétel, valamint a munkaerö-közvetítés terén.

10 Juhász Ferenc - Juhász Júlia - Nagy-Mitró Lilla - Somogyi Zsófia Borbála: i. m. 34-35. o. 


\section{Utógondozás}

Az utógondozás olyan, a bv. pártfogók által végzett jogintézmény, amely a szabadultakat önkéntes vállalásuk alapján, szabadulásuk időpontjától kezdődően maximum egy éven keresztül segíti a szabad életben való eligazodásban. Az elöbbiekben felsorolt, reintegrációs gondozásba tartozó tevékenységi körök mindegyike megjelenhet az utógondozás alatti segítő folyamat során. Az utógondozás Magyarországon jelenleg nagyon szük kört érint, ennek oka abban keresendő, hogy a szabadultak - hiába az utógondozásról való tájékoztatás a reintegrációs gondozás idején - saját maguk veszik kézbe ügyeik intézését még akkor is, ha azokkal kevesebb sikert érnek el, mint várják. Másrészt a tapasztalatok azt mutatják, hogy a szabadultak nagyon nehezen orientálhatók olyan segítségnyújtási forma irányába, amely tőlük bármiféle alkalmazkodást, önerőt, önszorgalmat kíván, nehezen vonhatók be az utógondozás, illetve egyéb, önkéntes részvételen alapuló szerveződésbe.

\section{Pártfogó felügyelet}

A pártfogó felügyelet végrehajtása a bv. pártfogói tevékenység legmarkánsabb része, ahol a kontroll és támogató funkciók leginkább megjelennek. Különösen fontos ez a szabadulás utáni hat hónapban, ez a visszaesés tekintetében a legkritikusabb időszak. ${ }^{11}$ A pártfogó felügyeletre felkészítés már a bv. intézetben megkezdődik, hiszen a reintegrációs gondozás keretében a bv. pártfogók kioktatják a szabadulás előtt állót a pártfogó felügyelet céljáról, szabályairól és az ahhoz kapcsolódó fontos információkról.

A munkaerőpiaci integráció érdekében a foglalkozatási föosztállyal való kapcsolatfelvételt - mint a sikerhez vezető egyik lehetséges utat - a bv. pártfogó hangsúlyozza, és ellenőrzi a megjelenési kötelezettségek idején. A bv. pártfogónak nagy szerepe van abban, hogy motivációs beszélgetések alkalmával olyan irányba terelje a pártfogoltak jövőre vonatkozó elképzeléseit, amelyek között a bejelentett, hosszú távú munkalehetőség tölti be a központi szerepet, amelynek legelső állomása az álláskeresőként való regisztráció lehet.

11 Pálvölgyi Ákos: A társadalom részvételének szükségessége a büntetés-végrehajtásban (reszocializáció, reintegráció). Büntetőjogi Szemle, 2014/2., 77-84. o. 


\section{Az eddigi eredmények bemutatása}

Noha a bv. pártfogók teljes létszáma nem éri el a hatvanat, mégis rendkívül sokat tesznek a büntetés-végrehajtás érdekében, ezek közül jelen esetben csupán a pártfogó felügyelet számadatait ismertetem. Országos szinten a 2017. július 31-i állapot szerint a pártfogó felügyelet végrehajtása 2717 folyamatban lévő ügyet jelent (a pártfogolt személyek száma némileg alacsonyabb, tekintve, hogy egy pártfogoltnak több, párhuzamos ügye is lehet). 2015. január 1. után vannak statisztikai adataink, 2015 januárjától 2017 júliusáig csaknem hatezer pártfogolt ügyében rendeltek el pártfogó felügyeletet. ${ }^{12}$

A bv. pártfogók által felvetett igényhez igazodva a BVOP Fogvatartási Ügyek Szolgálata pártfogó felügyelői osztály a bv. pártfogók közremüködésével 2017 júliusában a még hatékonyabb munkaerőpiaci integráció érdekében olyan országos adatbázist hozott létre, amely megyei felosztásban tartalmazza a szabadultakat alkalmazó munkáltatók nevét és elérhetőségét, valamint a betölthető munkakörök megnevezését és az esetleges, munkáltatók által biztosított szálláslehetőségeket is. Ennek pozitív hatása várható a szabadultak munkába állásának elősegítése érdekében. Ezen túl, mint már említettem, a BVOP és a bv. intézetek szoros kapcsolatot építettek ki a kormányhivatalok foglalkoztatási főosztályaival.

A középirányító szerv és a bv. intézetek reintegrációs szakterületei jókora erőfeszítéseket tesznek a szabadultak elhelyezkedésének sikeressége érdekében, miközben ennek eredményessége hazánkban régiónként jelentős eltéréseket mutat a munkaerő-kereslet/-kínálat függvényében, ami a szabadultakon túl ugyanilyen mértékben érinti a társadalom egyéb, munkaképes szereplöit is. A továbbiakban az elhelyezkedési esélyek nehézségeit a teljesség igénye nélkül, a pártfogoltak és utógondozottak csoportját együtt tárgyalva mutatom be.

\section{A munkaerőpiaci integráció kérdései a pártfogoltak és utógondozottak körében}

$G a ́ l^{13}$ az általa végzett kutatás nyomán megfogalmazza, hogy a munka a szabadult fogvatartott egyetlen esélye a társadalomba való integrálódásra. A munkaerőpiaci integráció valóban fontos tényezője a szabadulás utáni integ-

12 A bv. szervezet nyilvántartása szerint.
13 Gál Levente: A munkaerőpiacon innen, a börtönön túl. In: Albert Fruzsina (szerk.): i. m. 23-59. o. 
rációnak, ám nem feledkezhetünk meg a többi körülményröl sem, amilyen például a szociális támogató háló megléte vagy hiánya.

Az utógondozott és a pártfogolt, valamint a bv. pártfogó közötti kapcsolat relatíve hosszú időn át fennáll, utógondozás esetén maximum egy, pártfogó felügyelet esetén minimum egy, maximum tizenöt évig, így - egyebek között - a munkaerőpiaci integráció pozitív irányú elmozdulását megalapozó kapcsolat jöhet létre a két fél között. A bv. pártfogó elsődlegesen saját ismeretségi tőkéjét felhasználva tud konkrét munkáltatót ajánlani a szabadultnak, aki sok esetben csak látszólag motivált az elhelyezkedésre, amelynek érdekében erőfeszítéseket leginkább a bv. pártfogó elvárásainak való megfelelési kényszer miatt tesz. A bv. pártfogónak sokszor nagyobb feladat a motiváció felkeltése, mint egy lehetséges munkahely felkutatása. Természetesen ez nem mondható el általánosan, hiszen a sikeres elhelyezkedés végkimenetelét mind a személyes jellemzők, mind az adott régió munkaerőpiaci helyzete befolyásolja. Alapesetben a bv. pártfogó együttmüködés keretében a területileg illetékes munkaügyi szervhez irányítja a szabadultakat. Itt megtörténik a regisztrációjuk, de a folyamat sok esetben ennél a szakasznál megreked, és azon kívül, hogy a szabadult regisztrált álláskeresővé válik, nem sikerül szakmai végzettségének - már ha van ilyen - megfelelő munkát vállalnia a munkaügyi szerven keresztül. A szabadultak körében sok esetben találunk hiányos vagy alacsony képzettségüeket, akik az általános iskola nyolc osztályát vagy ennél kevesebbet végeztek. Esetükben gyakori, hogy a közfoglalkoztatás keretén belül sikeresen elhelyezkednek, de több olyan eset is előfordult, hogy a szabadultat nem foglalkoztatták közfoglalkoztatás keretében, mert teljesen feltöltöttek voltak a státusok. Ez különösen jellemző azokra a régiókra, amelyekben magas a munkanélküliség, és kevés a munkát adó foglalkoztató.

Általánosságban elmondható, hogy a pártfogoltak és az utógondozottak elhelyezkedése a halmozottan hátrányos helyzetủek körében a legnehezebb. Esetükben a munkára való motiváció is hiányzik, nem ismerik a strukturált időt, nem tudnak szabályokhoz alkalmazkodni, vagy a nehézségeiket normakövető módon rendezni, gyakori a szenvedélybetegség is, így szinte lehetetlen a beilleszkedésük a munkakörnyezetbe.

Összességében kijelenthető, hogy szabadultként munkát találni közel sem egyszerü. Miközben a statisztikák azt mutatják, hogy rengeteg betöltetlen álláslehetőség kínálkozik a munkakeresőknek, a kereslet és a kínálat nem találkozik. Különösen igaz ez a börtönből érkező, hátrányos helyzetű szabadult esetében. Mindenki jól ismeri a hatósági erkölcsi bizonyítvány fogalmát, a büntetett elöélet feltüntetése rendkívül negatív tényező a munkakereséskor. A szabadu- 
lás után - az ítélet tartamához igazodva - a terheltek három, öt, nyolc, illetve tíz évig viselik a hátrányos jogkövetkezmény e formáját. Különösen azoknál a szabadultaknál gond ez, akiknek megfelelö, keresletképes végzettségük van, ám az elhelyezkedésük az erkölcsi bizonyítványban bejegyzettekre tekintettel szük korlátok közé szorul. Gál ${ }^{14}$ az általa végzett kutatás alapján úgy véli, hogy a munka világában általános feltétel az erkölcsi bizonyítvány, és már nemcsak a valóban feddhetetlenséget igénylő munkáknál, hanem lényegében minden munkakörben. A mentesítési mutatók pozitív irányba történő elmozdításának érdekében fontos lenne a bv. pártfogó felügyelők által azon információra való felhívás, hogy a mentesítés hol, mikor, milyen formában kérhető.

Természetesen nem csupán az erkölcsi bizonyítványban foglalt bejegyzés okozza a munkanélküliséget, hanem a hiányzó szociális feltételek, az indulatkezelési problémák, a szenvedélybetegségek stb. Ezeket bv. pártfogóként komplexen kell figyelembe venni, és ehhez igazítani a személyre szabott segítő- és kontrollfunkciók alkalmazását.

A bv. pártfogók a szabadultak pártfogó felügyeletét és utógondozását nem csupán saját forrásaikra támaszkodva látják el, ezért szükséges a közremüködésbe bevonható szervekről és szervezetekről is szót ejteni.

\section{A külső szervek és szervezetek szerepe a munka világába történő visszavezetésben}

Schmehl is megfogalmazta, hogy „A szabadságvesztés-büntetés végrehajtásának operativ célja az elitélt reintegrációjának elömozdítása, amelynek kiteljesitéséhez széleskörü társadalmi összefogásra van szükség""I5. Ahogyan korábban említettem, a foglalkoztatási főosztályokkal való együttmüködéssel lehetőség nyílt a bv. pártfogók számára, hogy tájékoztatást kapjanak az éppen aktuális képzésekről, munkalehetőségekrooll. Mindemellett fontos az egyéb, civil vagy egyházi szervezetekkel való jó együttmüködés kialakítása is. Általánosságban elmondható, hogy ,, a civil szervezetek a társadalmi kulturális élet fontos alkotóelemei, tevékenységük, szerepvállalásuk révén nagymértékben hozzájárulnak a társadalmi problémák hatékony kezeléséhez, a közösségi szükségletek kielégitéséhez"' ${ }^{\text {. }}$. A bv. pártfogók tevékenységi köréhez a társadalmi

14 Uo

15 Schmehl János: i. m. 2. o.

16 Nárai Márta: A civil szervezetek szerepe és jelentősége az egyének, közösségek, illetve a társadalom számára. Politikai szocializáció, 2004/4., 616. o. 
szervezetek leginkább azon köre kapcsolódik, amelyek fő profilja a szociálisan, anyagilag rászorult emberek segítése, e csoportba a szabadulás után a volt fogvatartottak egy csoportja is beleillik. E szervezetek gyakran kapcsolatban állnak a hajléktalanellátó rendszerrel, illetve munkáltatókkal is. A szabadulás előtt állók - különösen azok, akiket nem vár támogató családi légkör, illetve munkalehetőség - igénylik e szervezetek elérhetőségét a reintegrációs gondozás tartama alatt. Azonban különösen azok a nehezen irányítható egyének, akik csupán felszínesen érdeklődnek a lehetőségek után, de valójában maximálisan elutasítanak mindennemü segítséget, és az együttmüködési készségük alapjában véve hiányzik, a bv. pártfogó által az alapítványokkal, egyéb szervezetekkel történő előzetes egyeztetés, időpont-megbeszélés után nem jelentkeznek a fogadó szervezeteknél. Tény, hogy hazánkban jelenleg kevés olyan szerv/szervezet müködik, amely konkrét munkalehetőségeket tudna ajánlani kifejezetten szabadultak számára. Pozitívumként értékelhető azonban, hogy a közelmúltban egyre több cég kereste meg a BVOP-t, amelyek képzésekkel egybekötött munkalehetőséget kínálnának a szabadulás előtt álló elítéltek részére. Ezekkel a szervezetekkel - amelyek között európai uniós forrásból finanszírozott is található - az egyeztetések folyamatosak, így ezeket még részletesebben tárgyalom.

Az egyházi szervezetek képviselői minden bv. intézetben jelen vannak, ám az általuk nyújtott segítség elsősorban a hívők számára elérhető. Több olyan eset ismert, ahol a lelkészen keresztül az egyház kínált lakhatást és munkát a szabadultnak, ám ez a fajta segítség a fogvatartott és az egyházat képviselő személy, leginkább a börtönlelkész közti hosszú távú kapcsolaton alapul, és eseti jelleggel történik.

Meg kell említenem azt a törvény által nyújtott lehetőséget, amely a tíz vagy annál több évet folyamatosan szabadságvesztésben töltő fogvatartottak szabadulás utáni reintegrációját igyekszik elősegíteni. A Bv. tv. 191. § (5) bekezdése megfogalmazza azt az állami szerepvállalást, amellyel az utógondozásban részt vevő, hosszú ítéletből szabaduló fogvatartott lakhatásának és munkába állásának lehetőségéről gondoskodik. Ennek megvalósulása elsősorban az önkormányzatok vagy önkormányzati fenntartású intézmények, valamint a munkaügyi szervek útján ölthet testet. Tekintve, hogy a Bv. tv. e rendelkezéséröl kevesen tudnak, szükséges párbeszédet kezdeményezni az érintett területek képviselőivel, valamint az állam által nyújtott effajta szerepvállalás társadalmi elfogadtatása is közös feladat.

A munkaerőpiaci integráció kiteljesedését gátló jogszabályi környezetet a következökben mutatom be, ezt meg kell említenem annak érdekében, hogy teljesebb képet kaphassunk a munkába állást nehezítő tényezők sokszínüségéről. 


\section{A jogharmonizációs törekvések szükségessége}

Külföldre utazás

Az Albert és Biró ${ }^{17}$ által végzett kutatás alapján megállapítható, hogy a szabadultak mintegy negyven százaléka tervezi a külföldi munkavállalást. Ez egyrészt következhet a korábbiakban részletezett erkölcsi bizonyítvány bejegyzéseiből fakadó kilátástalanság érzéséből, de más tényezők, például a jobb megélhetés reménye, a kiszakadás a veszélyeztető környezetből vagy éppen a családtagokkal való egyesülés stb. is befolyásoló erőként hat a szabadulókra.

A külföldre kiutazás lehetősége minden olyan volt fogvatartottnak adott, akik letöltötték a büntetésüket, és kedvezmény nélkül szabadultak. Figyelembe kell vennünk azonban azt a fogvatartotti populációt is, akik feltételes kedvezménnyel szabadulva hagyják maguk mögött a bv. intézetet.

Magyarországon a külföldre utazásról szóló 1998. évi XII. törvény egyértelmüen kimondja, hogy a szabadságvesztés végrehajtásának utolsó napjáig nem gyakorolhatja a külföldre utazás jogát az a személy, akit végrehajtandó szabadságvesztésre ítéltek. ${ }^{18}$

Mint ahogyan azt tudjuk, a feltételes szabadság tartama alatt a büntetés nem számít letöltöttnek, így e törvény értelmében a feltételes kedvezménnyel szabadulók nem élhetnek a külföldre utazás lehetőségével (sem személyazonosító igazolvánnyal, sem útlevéllel, utóbbi kiadását egyébként a hatóság a büntetés kitöltésének napjáig visszatartja).

A feltételes szabadság mellett megállapított szabályok más uniós tagállamba való átadásáról - köztük a pártfogó felügyeletről is - találunk törvény adta lehetőséget, erről a 2016. évi CIII. törvény rendelkezik. E rendelkezések előremutatók ugyan a pártfogó felügyelet másik tagállamba való áttételét illetően, de alkalmazásuk a gyakorlatban igen ritka, hiszen a pártfogoltak nagy része csupán munkavállalás céljából utazna külföldre, ahonnan bizonyos időszakonként hazatér Magyarországra, továbbá a pártfogó felügyelet ügyének áttételét a szabadult hiányos idegennyelv-ismeretéből fakadóan sem kívánja igénybe venni.

A pártfogó felügyelet alatt állók külföldre kiutazásának problémája a bv. pártfogók számára is gondot okoz. Egyes esetekben bv. pártfogóként nehéz megtiltani a szabadultnak a kiutazás lehetőségét, hiszen a reintegrációja érde-

17 Albert Fruzsina - Biró Emese: i. m

18 1998. évi XII. tv. 16. § c), ca) 
kében éppen ez adná meg a kellő motivációt ahhoz, hogy a visszaesését megelőzzük. A bv. pártfogónak feladatellátása során a törvényi rendelkezéseknek megfelelően kell ellátnia munkáját, de azok szakmai szempontok szerint a külföldre utazással kapcsolatban aggályosak, így szükséges egységes jogi szabályozás megalkotása.

\section{Reintegrációs örizet}

A reintegrációs őrizet jogintézményének 2015. április 1-jei bevezetésével a társadalomra kevésbé veszélyes, nem életvitelszerü bünelkövetők számára lehetőség nyílt arra, hogy elektronikus nyomkövető alkalmazásával büntetésük utolsó hat hónapját az általuk megjelölt és büntetés-végrehajtási bíró által engedélyezett lakásban vagy házban tölthessék, ha az megfelel a jogszabályok által meghatározott kritériumoknak.

A Bv. tv. reintegrációs őrizetbe helyezésre vonatkozó rendelkezései 2017. január 1-jén módosultak, ebből adódóan a jogintézmény alkalmazására jogosult fogvatartottak száma megemelkedett, a tanulmány készítésének idején 320 -an töltik reintegrációs őrizetüket. ${ }^{19}$

A reintegrációs őrizet a teljes szabadságelvonás és a felelős önálló életvezetés közötti, eddig fennálló hézagot tölti ki egy az állami szervek által felügyelt, legfeljebb tíz hónapig, illetve egy évig tartó szakasszal. Ebben a periódusban az elítéltnek lehetősége nyílik gondoskodnia az önálló megélhetéséröl, munkát kereshet és vállalhat, tanulmányokat folytathat, valamint erősítheti és újraalakíthatja családi, társadalmi kapcsolatait.

A jogintézmény alatt állók kapcsán meg kell említeni egy olyan jogszabályi anomáliát, amely a munkába állás lehetőségét korlátozza. A foglalkoztatás elösegitéséről és a munkanélküliek ellátásáról szóló 1991. évi IV. törvény (a továbbiakban: foglalkoztatási törvény) kimondja, hogy az álláskeresőként történő nyilvántartásba vétel szünetel a szabadságvesztés időtartama alatt. ${ }^{20}$ Mivel a reintegrációs örizetbe helyezett fogvatartottak büntetés-végrehajtási jogviszonya még fennáll, a foglalkoztatási fóosztályok sok esetben megtagadják az álláskeresőként való regisztrációjukat, így a közfoglalkoztatás keretén belül sem tudnak munkát vállalni, illetve képzésben részt venni. Ez különösen azokon a területeken okoz problémát, ahol a nyílt munkaerőpiac adta lehetőségek meglehetősen korlátozottak, és magas a munkanélküliség. A

19 A bv. szervezet nyilvántartása szerint.

20 1991. évi IV. törvény 54. § (14a) bekezdés f) pont. 
gyakorlat a kormányhivatalok foglalkoztatási főosztályainak kirendeltségein megyei szinten sem egységes, a bv. pártfogók visszajelzései alapján több helyen ugyanis a Bv. tv. reintegrációs célkitüzéseit előtérbe helyezve mégis regisztrálják a kihelyezetteket.

Egy 2017 májusában készült adatszolgáltatás kapcsán megállapítható, hogy a jogintézmény bevezetése óta a 2017 májusáig reintegrációs örizetbe helyezett összes fogvatartotti létszám 962, közülük 512-en vettek részt valamely képzésben vagy helyezkedtek el a munkaerőpiacon, illetve álláskeresőként regisztráltak az illetékes munkaügyi szervnél. Az előbbieket is beleértve, a kihelyezettek 53 százalékának megoldott az anyagi ellátása akár a közfoglalkoztatás vagy egyéb bejelentett munkaviszony, akár alkalmi munka vagy egyéb ellátás alapján.

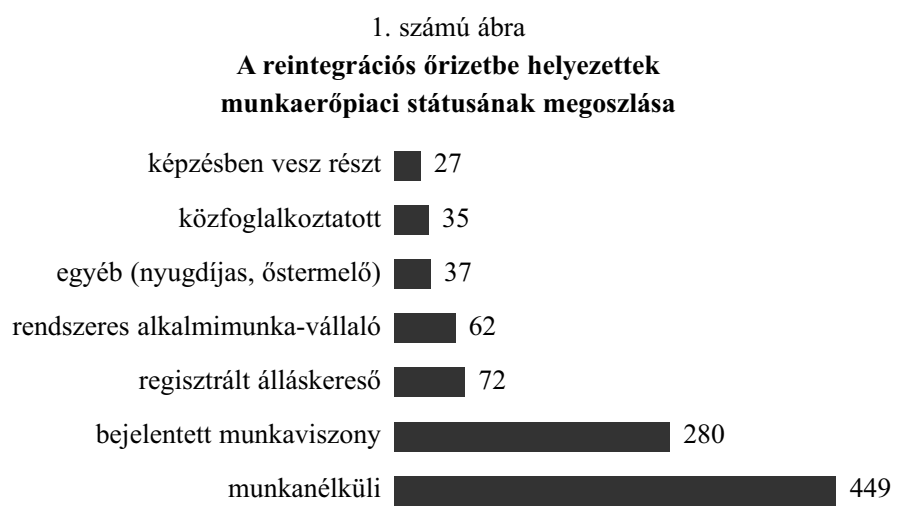

Az előbbiekben vázolt jogi szabályozás ellenére - amely az álláskeresőként való regisztrációt akadályozza - pozitívumként értékelhető, hogy a reintegrációs örizetbe helyezettek több mint fele sikeresen elhelyezkedett, megélhetéséről képes önállóan gondoskodni.

A tanulmány kapcsán a munkába állást nehezítő tényezők felmérésén túl európai országok körében folytattam vizsgálatot annak érdekében, hogy feltárjam azokat az esetleges jó gyakorlatokat, amelyek kamatoztatása a magyar gyakorlatban pozitív elmozdulást jelenthetne. 


\section{Nemzetközi kitekintés}

Európai viszonylatban egyedülálló az a magyarországi szervezeti struktúra, amelyben a büntetés-végrehajtás a Belügyminisztérium irányítása alatt müködik, és amelybe a pártfogó felügyelői tevékenységek egy része integrálódott 2014-ben. Más országokban a büntetés-végrehajtási szervezet jellemzően az Igazságügyi Minisztérium alá tartozik, ahogyan külön szervezetbe tagozódva a pártfogó felügyelői rendszer is.

A tanulmány elkészítésekor nemzetközi kapcsolatokon keresztül sikerült teljesebb képet kapni a környező államok pártfogó felügyelői rendszeréről, valamint azok müködési tapasztalatairól. A felméréshez nyolc ország (Ausztria, Csehország, Horvátország, Németország, Románia, Szerbia, Szlovákia, Szlovénia) megkeresésére került sor a BVOP koordinációs főosztályának segítő közremüködésével. A válaszadási arány az országok körében ötvenszázalékos volt, végül Szlovénia, Csehország, Horvátország, Románia mellett Litvánia is küldött válaszokat. A válaszadók bizonyos kérdésekre - feltehetöen a feltett kérdések teljesen más szervezeti struktúrára való átültetésének nehézsége miatt - csak részben válaszoltak.

Általánosságban elmondható, hogy a környező országokban a pártfogóknak kevés szerep jut a szabadulás előtti felkészítési folyamatban, tevékenységük elsősorban a szabadulás utáni pártfogó felügyeleti feladatok ellátására fókuszál. Ezzel ellentétben egyedülálló az a hazai gyakorlat, amelyben a bv. pártfogó a reintegrációs tevékenységet már a szabadulásra történő felkészítés keretében is végzi, abban markáns szerepet vállal, majd ez után több ügykörön keresztül az utánkövetést is megvalósíthatja a támogató és kontrollfunkció érvényesítésével.

A környező országokból kapott információk a következőkben foglalhatók össze.

\section{Szabadulásra felkészítés}

Mivel a reintegráció nem a büntetés végrehajtásának záróakkordjaként képzelendő el, vázolom az országok erre vonatkozó gyakorlatát.

Minden ország - hazánkkal megegyezően - fontosnak tartotta hangsúlyozni, hogy már a befogadás után megkezdődik a fogvatartottak esetkezelése, a szabadulásra való felkészítésük folyamata. 


\section{Románia}

A feltételes szabadulás előtt három hónappal kezdődik meg a szabadulásra való felkészítés, amelyben a pártfogó mellett több szervezet is részt vesz. A reintegrációs törekvések, tanácsadások, bevonható szervezetek körét kormányhatározat szabályozza. Romániában a szabadságvesztésük utolsó részét töltő fogvatartottak részt vehetnek úgynevezett ,job fair”-en, amelyet munkaerö-közvetítők tartanak az aktuális elhelyezkedési lehetőségekröl, továbbá adott esetben munkáltatói elöszerződést is köthetnek velük még a bv. intézetben, így a szabadulásuk után lesz munkahelyük.

\section{Szlovénia}

A bv. intézetek szociális munkásai végzik a reintegráció fő feladatait, náluk is a szabadulás előtt három hónappal kezdődik meg a felkészítés. Érdekesség, hogy a fogvatartottak a szabadulásuk elött hat hónappal - még a bv. intézetből - regisztrálhatnak álláskeresőként a munkaügyi hivatalnál. Szlovéniában jelenleg nem müködik önálló pártfogó felügyelői szolgálat.

\section{Litvánia}

A szabadulás előtt állók - ha igénylik - segítséget kaphatnak munkahely, illetve lakhatási lehetőség megteremtéséhez. Szabadulásra felkészítésüket komplexen végzik pszichológusok, szociális munkások és különböző segélyszervezetek munkatársai.

\section{Horvátország}

Az eddigiekkel megegyező időtartamban, a szabadulás előtt legkésőbb három hónappal az elítéltek személyes vagy csoportos szabadulásra felkészítő tanácsadáson vesznek részt. Ha nem rendezett a lakhatásuk, akkor a bv. intézet felkeresi az illetékes szerveket az elhelyezés megoldása érdekében.

\section{Csehország}

A szabadulásra való felkészítésért felelős bizottság nevelőből, pedagógusból, szociális munkásból, pszichológusból és úgynevezett szabadidős tevékenységekért felelős pedagógusból áll. A szabadulás előtt legfeljebb hat hónappal 
egy intenzív, a felkészülést elősegítő kezelési programot is indítanak. Csehországban különös gyakorlat, hogy a fogvatartotti munkavégzés minősége alapján a bv. intézetben jelenlévő, ott munkáltatást végző cég teljes munkaidős beosztást kínál a szabadultnak, többen közülük szállásról is gondoskodnak. Ez hazánkban csak eseti jelleggel történik.

\section{Munkaerőpiaci integráció}

A feltételesen szabadlábra helyezettek munkaerőpiacra történő visszatérésének vizsgálata során Litvánia pontos számadatokat szolgáltatott, e szerint a 2017. március 31-i állapot alapján a pártfogó felügyelöi szolgálat által ellátott 939 személyből 605 feltételesen szabadlábra helyezett elítélt (62 százalék) tudott munkát találni, 291-en (30 százalék) regisztrált álláskeresők, 30-an (3 százalék) pedig oktatásban vettek részt. E számarányok a munkaerőpiaci integráció kapcsán felülmúlják ugyan a magyarországi számokat, de megjegyzendő, hogy a pártfogoltak száma hazánkban több mint háromszorosa a litván számadatoknak. Magyarországon pártfogó felügyelet alatt 2017. júliusban 2717 ügyben 2572-en álltak, közülük 604-en (23,5 százalék) munkanélküliek, 1012-nek (39,3 százalék) rendben van a megélhetése akár bejelentett vagy alkalmi munka, közfoglalkoztatás, egyéb ellátás, illetve nyugdíj címén. Képzésben tízen vettek részt. ${ }^{21}$ Meg kell említeni azt is, hogy a pártfogó felügyelet alatt állók több mint harminc százalékának nincs megadva munkaerőpiaci státus a bv. pártfogók által használt nyilvántartási rendszer adatai szerint. Ennek oka egyebek között, hogy a pártfogoltak egy része (474fö) még szabadságvesztés-büntetését tölti, ezért ezen adatok kitöltése a bv. pártfogók részéről nem releváns.

A nemzetközi kitekintésen túl a tanulmány során elengedhetetlennek tartottam a munkaerőpiaci integrációban leginkább érintett célcsoport, a pártfogó felügyelet alatt állók kérdőíves vizsgálatát. Azért is fontos ez, mert a középirányító szervnek vannak ugyan statisztikai adatai a pártfogoltak munkaerőpiaci státusáról és annak alakulásáról, de korábban még nem készült közvetlenül az érintettektől központi, a megkérdezettek szubjektív válaszaira épülő adatgyüjtés.

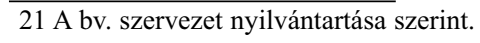


2. számú ábra

A pártfogoltak munkaerôpiaci státusának megoszlása Magyarországon

képzésben vesz részt | 10

pártfogó segítségével elhelyezkedett | 11

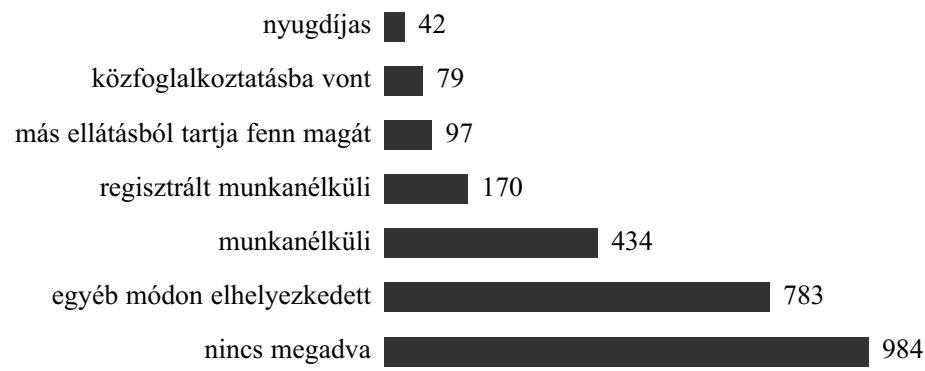

\section{Kutatási eredmények}

A tanulmány elkészítése során tehát pártfogó felügyelet alatt állók kérdőíves felmérésére került sor, amelyben munkaerőpiaci integrációjuk folyamatáról tettünk fel kérdéseket a következők szerint:

- mennyire érzik hátránynak azt a tényt, hogy büntetett előéletủek;

- szabadulásuk után mennyi idővel tudtak elhelyezkedni;

- milyen konkrét munkakörben dolgoznak;

- ki segítette őket az elhelyezkedésben;

- mennyi az átlagos havi jövedelmük;

- mivel tudná segíteni a bv. pártfogó az elhelyezkedésüket.

Mint ahogyan azt korábban említettem, a vizsgált időszakban 2572-en álltak pártfogó felügyelet alatt. A kutatási időszakban 108 pártfogolt vállalta önként a kérdőív kitöltését. A rendelkezésre álló válaszok számából jól látható, hogy a felmérés által hozott statisztikai adatok nem tekinthetők általános érvényünek és reprezentatív jellegünek sem, ezt mindenképpen szem előtt kell tartanunk az eredmények értékelésekor. A kérdőívek felvételére tizenhárom bv. intézet bv. pártfogóit kerestem meg az ország különböző pontjain, elkerülendő a válaszokat befolyásoló regionális szintű tendenciát, amely az ország keleti felének vizsgálatakor a kedvezőtlen elhelyezkedési esélyek miatt az átlagosnál alacsonyabb, míg a nyugati fele magasabb elhelyezkedési arányt, ezáltal szélsőségesebb eredményeket hozott volna.

A kérdésekre adott válaszok a következőkben összegezhetők. 
A válaszadók 36,4 százaléka egyáltalán nem érzi problémásnak a büntetett előélet adta elhelyezkedési lehetőségeket, miközben 29 százalékuk nagy problémaként, 28 százalékuk pedig problémásként definiálta, így tehát 57 százalékuk szerint problematikus a munkához jutás büntetett előéletüként, további 2,8 százalék véli úgy, hogy teljes mértékben ellehetetleníti a munkához jutást. Ebből az eredményből jól látszik, hogy a pártfogó felügyelet alatt állók - ahogy azt korábban kifejtettem - valóban nehézkesnek élik meg a szabadulás utáni elhelyezkedést.

A szabadulás utáni elhelyezkedéshez szükséges idő vonatkozásában az látható, hogy a válaszadók 39,3 százaléka két héten, 28 százalékuk egy hónapon, 13 százalékuk három hónapon belül el tudott helyezkedni. Egyáltalán nem tudott munkába állni 9,3 százalékuk, 5,6 százalékuk inaktív munkaerőpiaci státusú (például nyugdíjas).

A betöltött munkakörök kapcsán elmondható, hogy a válaszadók többsége olyan pozícióban dolgozik, amely betanított jellegü, illetve segédmunka, emellett meghatározó a szakmunkások száma is, utóbbi kettő leginkább az építőipar területén jellemzö. Foglalkoztatási jogviszonyukról megállapítható, hogy a megkérdezettek több mint felének (54,2 százalék) rendszeres, bejelentett munkaviszonya van, ennek elérésében részben a bv. pártfogók is közremüködtek. Ezt követi az alkalmi munkások száma (26,3 százalék), majd a munkanélküliek aránya $(12,1)$.

A munkába álláshoz való segítségnyújtás kapcsán megállapítható, hogy a válaszadók 46,7 százaléka a bv. pártfogó mellett a családi, baráti kapcsolatokat és az ismeretségi kört jelölte meg mint támogatói kört. Ebből 41,6 százalék kért további segítséget nemcsak a munkába állással, de egyéb ügyeivel (életvezetés, segélyhez jutás stb.) kapcsolatban is a bv. pártfogótól. További 29,9 százalékukat visszavárták régi munkahelyükre, illetve önerőből találtak munkát, így segítséget nem igényeltek; 9,3 százalékuk nyilatkozott úgy, hogy kizárólag a bv. pártfogó segítette őket munkához. Ezekből az eredményekből kitünik, hogy két domináns csoport különíthető el a pártfogolti populációban. Egyik részük családi, baráti kapcsolatai által, illetve önerőből oldja meg elhelyezkedését, másik részük ebben a bv. pártfogó felügyelő segítségét kéri. Utóbbi számadatok a megkérdezettek azon javaslatait is tartalmazzák, amelyek a konkrét bv. pártfogói segítségnyújtásra irányulnak. Hangsúlyozandó, hogy többségük azt szeretné, ha szabadulásuk után a bv. pártfogó azonnal munkalehetőséghez juttatná őket. Sokan az információáramlást, a munkalehetőségek naprakész ismeretét fogalmazták meg bv. pártfogói támogatási lehetőségként. 
A pártfogoltak 47,9 százalékának száz- és kétszázezer forint közötti a havi bruttó átlagjövedelme, 31,8 százalékuk ötven-százezer forintot keres, 9,3 százalékuknak kétszázezer forint feletti jövedelme van. Ezzel szemben 8,4 százalékuknak abszolút nincs vagy maximum ötvenezer forint a jövedelme, utóbbi kör nagyjából lefedi a munkanélküliek vizsgálatban megjelenő arányát. Magyarországon a 2017 januárjától júliusig tartó időszakban a Központi Statisztikai Hivatal szerint a bruttó átlagkereset 290300 forint ${ }^{22}$, ebből jól látható, hogy a pártfogoltak jövedelme jóval ez alatt van.

A korábban ismertetett jogszabályi környezet, a nemzetközi tapasztalatok és a kutatási eredmények alapján a továbbiakban különböző fejlesztési irányokat fogalmazok meg.

\section{A jövőbeli fejlesztési lehetőségek irányai}

Összességében elmondható, hogy az elmúlt időszakban megfigyelhető a szabadulás előtt állók és a már szabadultak munkaerőpiaci integrációjának pozitív irányú elmozdulása, a jelenlegi rendszer müködése részben elegendö ahhoz, hogy a bünismétlési kockázatok minimalizálását szolgálja, ám a fejlesztési lehetőségek továbbra is nyitva állnak.

A következőkben megfogalmazott lehetőségek csak társadalmi összefogással és az ellátórendszer fejlesztésével, illetve jogszabályi változtatással érhetők el, ez időigényes, ám kifizetődő lépés lehet a bünismétlés megelőzése érdekében.

\section{A társadalmi szerepvállalás erösitése}

A tanulmány megszólítja az igazságügy és a bv. pártfogói tevékenységek végrehajtásában partnerként részt vevő szervek és szervezetek képviselőit annak érdekében, hogy közös összefogással hatékonyabb eredmények szülessenek a szabadulók társadalmi reintegrációjában. Ahogyan ezt az előzőekben bemutattam, a bv. pártfogó feladatai között szerepel ugyan a segítő szervezetek tevékenységének összehangolása, de ez az elfoglaltság nem lehet egy csupán a bv. pártfogók részére fennálló egyoldalú feladat. A bv. pártfogó felügyeleti rendszer kialakítása óta jó eredmények mutathatók ki a társszervek-

22 KSH Gyorstájékoztató. Keresetek, 2017. január-június. 2017. augusztus 22.
https://www.ksh.hu/docs/hun/xftp/gyor/ker/ker1706.html 
kel való kommunikáció és együttműködés terén, ám az országos szintű öszszefogás - amely szükséges ahhoz, hogy a reintegrációs célok teljesebb eredményre vezessenek - még várat magára. A jelenlegi szociális ellátórendszer nincs teljes mértékben felkészülve a börtönből szabadult, lakhatási lehetőséggel nem bíró, halmozottan hátrányos helyzetüek ellátására és kezelésére. 2017-ben lehetóségem volt részt venni a Budapesti Módszertani Szociális Központ és Intézményei által szervezett szakmai napon, ahová pontosan ennek okán kértek fel kötetlen beszélgetés lefolytatására. Az átmeneti szállók, éjjeli menedékhelyek, egyéb szolgáltatást nyújtó intézmények személyzete érdeklődik a büntetés-végrehajtáson belüli, leginkább a szabadulásra való felkészítés tárgyában megvalósuló tevékenységek iránt, véleményük szerint ugyanis az ellátórendszerükben megjelenő szabadultak más kezelést igényelnek, mint a hajléktalanok vagy az egyéb hátrányos helyzetü emberek. Az elöbbiekböl is kiderül, hogy fontos lenne olyan intézmények létrehozása, amelyek felkészülten tudják fogadni a szabadulókat, és megfelelő tudásbázissal bírnak a bv. intézetből szabadulók pszichés státusa, szükségletei és a beavatkozási lehetőségek kérdésében. Éppen ezért fontos a félutas házak létjogosultsága is. A félutas ház olyan szolgáltatást nyújtó lakhatási lehetőséget kínál a szabadulóknak, ahol a lakhatás megoldása mellett a szakemberek a visszaesési kockázatuk csökkentését is megcélozzák. Általában szigorú házirend, kiválasztási rendszer jellemzi őket. Több európai országban müködnek félutas házak állami fenntartással, Dániában például nyolc, ezeket a pártfogó felügyelöi szolgálat müködteti. ${ }^{23}$

A Magyarországon müködő vagy korábban müködtetett félutas házak leginkább európai uniós forrásból (például a Váltó-sáv Alapítvány félutas háza), vagy egyházak (például Élő Reménység Alapítvány) által fenntartott, egyedi esetekben önkormányzatok saját esélyegyenlőségi programjain belül valósulnak/valósultak meg. A félutas házak több európai országban nemcsak a lakhatás megoldására fókuszálnak, hanem segítik a társadalmi integráció érvényesülését több szegmens vonatkozásában is, ez hazánkban is üdvözlendő lenne. A munkaerőpiaci integrációval kapcsolatos segítségnyújtás mindenképpen szerves része kellene hogy legyen a kialakítandó rendszernek, ezen túl egyéb kompetencia- és készségfejlesztő foglalkozások megtartása vagy az ilyen programokba való kiközvetítés is elképzelhető, akár más szervezetekkel való együttmüködések keretében.

\footnotetext{
23 Innovate to Empower. Convicts and non-convicts living together in a Danish halfway house. http://community.innovate2empower.project.emotiveprogram.org/blog/view/711/convicts-and-nonconvicts- living-together-in-a-danish-halfway-house
} 
Érdemes lenne tehát megfontolni egy olyan félutasház-rendszer kialakítását, amely konkrét és világos szabályozókkal és lehetőségekkel tudja fogadni a szabadulókat, akiknek a kiválasztása és felkészítése már a bv. intézetben megkezdődne - természetesen a bv. pártfogók segítő közremüködésével. Ahhoz, hogy a félutas házak reintegrációban betöltött létjogosultságát igazolhassuk, szükséges kidolgozni a szolgáltatás eredményességének mérését is (utánkövetés).

\section{A büntetés-végrehajtás szerepvállalása}

A büntetés-végrehajtásnak a fogvatartottak oktatása, képzése, munkáltatása az elsődleges feladata annak érdekében, hogy megelőzze a visszaesésüket. A bv. szervezet korábban is kiemelten kezelte a fogvatartottak foglalkoztatás keretében történő munkáltatását, oktatását és szakmai képzését, ezt a Bv. tv. még hangsúlyosabbá tette. Ez a törekvés jelenleg megvalósul, hiszen a munkaképes fogvatartotti állomány 87,9 százaléka vesz részt munkáltatásban, a foglalkoztatás aránya 89,7 százalék. ${ }^{24}$ A teljes körü foglalkoztatás megvalósítása mellett azonban megfontolandó lehet olyan egyéb előnyök kidolgozása, amelyekkel elérhető, hogy a képzésben való részvétel céljaként a részt vevő fogvatartottak egy része ne csak az ösztöndíjat lássa, hanem azt a törekvést, amely a foglalkoztatási rendszerük kidolgozása kezdetén megfogalmazódó jogalkotói szándék volt.

$$
\text { 2. számú kép }
$$

Kerékpártároló készítése Gyulán ${ }^{25}$

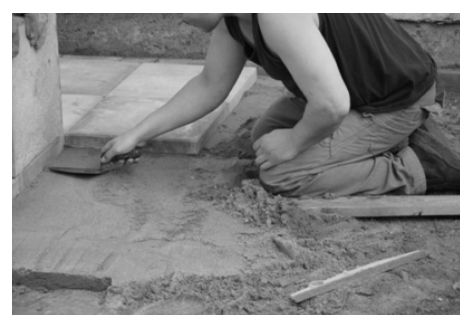

A fogvatartottak munkavégzése minőségbeli javulásának, illetve motiváltságuk megoldására a munkáért járó anyagi juttatások, esetleg egyéb, a fogvatartott bv. intézeten belüli életvitelére pozitív hatást gyakorló engedmé-

24 A bv. szervezet nyilvántartása szerint.

25 Fotó: Uhrin Ilona 
nyek, jutalmak magasabb szintre emelése lehetne további megoldás. Ismert olyan külföldi gyakorlat is, amelyben a fogvatartott büntetése a munkavégzés ellenében bizonyos mértékig csökkenthető.

Többször felvetődött már a fogvatartotti munkavégzés kapcsán, hogy a börtönben töltött évek alatt megvalósuló munkavégzés nem teremt nyugdíjalapot, ez szintén hátrányosan érinti a szabadulókat, különösen az időskorúakat. Péter ${ }^{26}$ már 1998-ban megfogalmazta, hogy a nyugdíjbiztosításba való bevonás nemzetközi szinten hiányzik. E státus egyebek között hazánkban a mai napig is fennáll. ${ }^{27} \mathrm{~A}$ társadalombiztositási nyugellátásról szóló 1997. évi LXXXI. törvény e rendelkezéseinek módosításával lehetőség nyílna ennek megváltoztatására akár oly módon is, hogy a fogvatartottak által végzett munka némileg alacsonyabb mértékben, de a nyugdíjat megalapozó szolgálati időnek minősülhessen.

A szabadulásra való felkészítést - amely természetesen elsősorban állami feladat - jelenleg a bv. pártfogók végzik a reintegrációs szakterülettel való szoros együttmúködésben, ugyanakkor érdemes lenne megfontolni társadalmi szervezetek ütemezett, a biztonsági szempontok maximális betartása mellett megvalósítható nagyobb fokú bevonását. A szabadulás előtti három-hat hónapban a munka világába történő sikeresebb beilleszkedés érdekében megfontolandó szorosabb, személyesebb kapcsolatot kialakítani a munkáltatókkal, akár munkaerő-közvetítői rendszer felállításán keresztül is, ahogyan azt Romániában is teszik. Pozitív hatást érhetünk el olyan munkaerő-közvetítő rendszer létrehozásával, amely országos szinten feltérképezi azokat a munkáltatókat, amelyek - akár eseti jelleggel is, de - foglalkoztatnának szabadulókat, természetesen a saját kiválasztási rendszerük mellett. Ez az intézmény akár a foglalkoztatási osztályok mellett, hasonló módszertannal, gyakorlattal is dolgozhatna, felmérhetné a „regisztráló” szabadulók iskolai végzettségét, tapasztalatát, az esetleges igényeket, majd ezek alapján ajánlana munkát a szabadulónak.

Az 1970-1980-as években Magyarországon léteztek úgynevezett „,védett munkahelyek", amelyek nagy számban foglalkoztattak börtönből szabadulókat különböző, jellemzően gyártósori tevékenységek ellátására. Közvetlen vezetőjük rendszeresen tájékoztatta a pártfogó felügyelőket a pártfogolt munkavégzésének minőségéről és az esetleges változásokról. E munkahelyek létjogosultságát a szabadulás utáni munkaerőpiaci integráció lehetősége adta,

\footnotetext{
26 Péter Zoltán: A munkáltatás és szakképzés szerepe a fogvatartottak életében. Szakdolgozat. Kézirat, 1998

27 1997. évi LXXXI. törvény 42. § (2) bek.
} 
de fel kívánom hívni a figyelmet arra, hogy a védett munkahelyek előnye egyben hátrányként is értékelhető, hiszen olyan módon kínált munkalehetőséget a volt fogvatartottaknak, hogy őket csoportosan, a törvénytisztelö munkavállalóktól elkülönítve helyezte el, munkakapcsolataik csupán a volt fogvatartott-társaikra korlátozódtak, ez aggályosnak tekinthető a visszaesés kockázatának tekintetében. Jelenleg is folynak egyeztetések a BVOP-n annak kapcsán, hogy néhány országos lefedettségü vállalat foglalkoztatna szabadult elítélteket, szigorú feltételek mellett (például csak az első fegyelemsértésig tartják fenn a jogviszonyukat). A jelenlegi elképzelés szerint e vállalatok a fogvatartottakat még a bv. intézet falain belül kiválasztanák, és felkészítenék a szabadulás utáni munkavégzésre, valamint a betöltendő munkakör szerinti feladatot be is tanítanák nekik azzal a feltétellel, hogy meghatározott időtartamig a cégnek dolgoznak majd (ez a gyakorlat Csehországban is megfigyelhetö). Fontosnak tartom kiemelni, hogy az elözőekben részletezett védett munkahelyeknél a jelenleg kialakulóban lévő rendszer megnyugtatóbb megoldást jelentene, mert a szabadulókat a munkáltatók a törvénytisztelő, polgári alkalmazottakkal együtt foglalkoztatnák, ezzel elkerülhető a volt fogvatartottak általi homogén csoportosulás, és az ezzel részben párhuzamba állítható visszaesési kockázat is alacsonyabbá válna.

Megjegyzendö, és fontos kiemelni azt is, hogy a szabadulók egy része teljes mértékben elhatárolódik a normakövető életmód kialakításától, egyúttal a munkavállalást is elutasítja, nem akar részese lenni a társadalmi szerepvállalásnak, nem akar beilleszkedni. Esetükben a bv. pártfogó első számú feladata a motiváció felkeltése, hiszen a vázolt lehetőségek, a munkaerőpiaci integrációban betöltött segítő közremüködés csak az után kaphat létjogosultságot, ha az elhatározás megtörtént - és sokszor ennek elérése a bv. pártfogó legnehezebb feladata.

\section{A jogszabály-módosítások lehetséges keretei}

A jogszabályi környezetre azért tértem ki, mert azok feloldása véleményem szerint mindenképpen szükséges. A külföldre utazás tiltása - tekintettel a nemzetközi bünügyi együttmüködésre - álláspontom szerint nem indokolt, sok esetben az eredményesebb reintegráció hiúsul meg egy-egy szabaduló életében az említett korlátozás miatt. A külföldre utazásról szóló törvény módosítása időszerü, hiszen lépést kell hogy tartson a megváltozott munkavállalási igényekkel, és szem előtt kell tartania, hogy itthon köztudottan nehéz a 
szabadulók elhelyezkedése. Ha a teljes engedélyezés nem is, akár részben támogatható lehetne olyan feltételekkel, amelyek befogadó nyilatkozathoz/bejelentett lakcímhez és bejelentett munkához kötik a pártfogó felügyelet alatt állók és a feltételesen szabadulók külföldre utazásának engedélyezését.

A reintegrációs őrizet jogintézménye sikeres, ám még inkább akkor teljesedhet ki, ha az álláskeresőként való regisztráció kapcsán megtörténik a foglalkoztatási törvény módosítása, ez megítélésem szerint szükséges és sürgetö. Különösen azon megyék vonatkozásában lenne ez elöremutató lépés, amelyekben a közfoglalkoztatásba való bekerülés adja az elhelyezkedési, megélhetési lehetőségek java részét, amiben pedig a jelenlegi jogi környezet miatt nem minden esetben vehetnek részt a jogintézmény hatálya alatt álló fogvatartottak.

Apróságnak tünik, de fontos lenne hangsúlyozni a munkaadók körében a korábban részletezett jogszabályt, amely a munkáltatók részére a szabaduló foglalkoztatása után járó szociális hozzájárulási adó kedvezményével vonzóvá teheti a foglalkoztatásukat.

A hosszú ítéletet töltők szabadulás utáni segítségnyújtásának az utógondozás keretén belül megvannak ugyan a törvényi keretei, ám szükséges azok megtöltése tartalommal, valamint kiterjesztése a pártfogó felügyelet alatt álló szabadultak körére. Ehhez szakmai egyeztetések szükségesek állami és egyéb külső szervezetekkel, továbbá ki kell dolgozni az érintettek lakhatási és munkaerőpiaci módszerének gyakorlati vázát.

\section{Összegzés}

A Gál ${ }^{28}$ által végzett utánkövetéses vizsgálat során a szabadulók által legtöbbször megnevezett igény a biztos munkahelyre, a megoldott lakhatásra, a központosított szervezeti segítségnyújtásra és szabadulás elött a külső viszonyokra történő felkészítésre vonatkozott. A tanulmányban bemutattam a munkaerőpiaci integráció szerepét a visszaesési kockázatok csökkentésében, ehhez kapcsolódva pedig bepillanthattak a bv. pártfogók által végzett tevékenységi körökbe, amelyeket részletesen bemutattam a munkaerőpiaci integrációval összefüggésben. Ennek középpontba állításával a bv. pártfogók által végzett áldozatos munka, annak szükségessége és súlya is megjelent, ez motivációs erőként hathat a felsőfokú tanulmányokat folytató hallgatók számá-

28 Gál Levente: i. m. 
ra annak érdekében, hogy tanulmányaik végeztével a bv. pártfogói hivatást válasszák.

A bv. pártfogó felügyeleti rendszer fennállása óta elért sikerek megismerése után az elhelyezkedést nem minden esetben megkönnyítő jogi környezetre és a szükséges társadalmi szerepvállalásra is igyekeztem rávilágítani annak érdekében, hogy a vázolt javaslatokkal, fejlesztési lehetőségekkel a szakma közelebb kerülhessen a még teljesebb feladat-megvalósításhoz.

A nemzetközi kitekintés teret engedett a környező országok gyakorlatának bemutatására, ennek alapján a magyar bv. pártfogó felügyeleti rendszer különlegesnek, szervezeti felépítésében egyedinek mondható, ezzel sokkal inkább szolgálja a szabadulásra való felkészítést is mindamellett, hogy a börtön kapuján való kilépés után is a volt elítéltek segítségére van. A kutatási eredmények - amelyek nem tekinthetők reprezentatívnak - igazolták, hogy a bv. pártfogóhoz lehet és érdemes is fordulni, ez a szakma létjogosultságát mutatja.

A tanulmányban megjelenő beavatkozási lehetőségek mind csak egy-egy lehetséges irányt vázolnak, azonban a későbbiekben az ez irányú elmozdulás pozitívumként hatna a visszaesési arányok csökkentésére.

\section{IRODALOM}

Albert Fruzsina - Biró Emese: A sikeres reintegráció. In: Albert Fruzsina (szerk.): Életkeretek a börtönön innen és túl. Szubjektív reszocializációs esélyek. MTA Társadalomtudományi Kutatóközpont, Budapest, 2015, 143-165. o.

Csima Beáta: Reintegrációs tevékenység a büntetés-végrehajtásban. Hadtudományi Szemle, 2015/2.

Gál Levente: A munkaerőpiacon innen, a börtönön túl. In: Albert Fruzsina (szerk.): Életkeretek a börtönön innen és túl. Szubjektív reszocializációs esélyek. MTA Társadalomtudományi Kutatóközpont, Budapest, 2015, 23-59. o.

Juhász Ferenc - Juhász Júlia - Nagy-Mitró Lilla - Somogyi Zsófia Borbála: A bűnismétlés megelőzéséhez kapcsolódó büntetés-végrehajtási pártfogó felügyelői szakmai feladatok. Segédanyag. H. n., 2017

Juhász Ferenc: A büntetés-végrehajtási pártfogó felügyelői tevékenység. Börtönügyi Szemle, 2015/2.

Nárai Márta: A civil szervezetek szerepe és jelentősége az egyének, közösségek, illetve a társadalom számára. Politikai szocializáció, 2004/4.

Pallo József: Modernizációs csomópontok „de lege ferenda” a magyar büntetés-végrehajtási jogban. Az Új utakon a magyar büntetés-végrehajtás címü, 2012. november 20-án megrendezett konferencián elhangzott előadás 
Pálvölgyi Ákos: A társadalom részvételének szükségessége a büntetés-végrehajtásban (reszocializáció, reintegráció). Büntetöjogi Szemle, 2014/2.

Péter Zoltán: A munkáltatás és szakképzés szerepe a fogvatartottak életében, Szakdolgozat. Kézirat. 1998

Schmehl János: A neveléstől a reintegrációig: a fejlődés útja a legjobb gyakorlatok tükrében. Börtönügyi Szemle, 2015/1.

Vigh József: Bűnismétlők, visszaesők, veszélyes bűnözők. In: Gönczöl Katalin - Korinek László - Lévai Miklós (szerk.): Kriminológiai ismeretek - Bünözés - Bünözéskontroll. Corvina Kiadó, Budapest, 1999, 243-252. o.

\section{JOGSZABÁLYOK}

A foglalkoztatás elősegítéséről és a munkanélküliek ellátásáról szóló 1991. évi IV. törvény A büntetés-végrehajtási szervezetről szóló 1995. évi CVII. törvény A társadalombiztosítási nyugellátásról szóló 1997. évi LXXXI. törvény A külföldi utazásról szóló 1998. évi XII. törvény Az Európai Unió tagállamaival folytatott bünügyi együttmüködésről szóló 2012. évi CLXXX. törvény

A büntetések, az intézkedések, egyes kényszerintézkedések és a szabálysértési elzárás végrehajtásáról szóló 2013. évi CCXL. törvény

A Pártfogó Felügyelői Szolgálat tevékenységéről szóló 8/2013. évi KIM rendelet

A fogvatartott személy esetében a büntetőeljárás lefolytatása során, továbbá a büntetőügyekben hozott határozatok végrehajtása során a bíróságokra és egyéb szervekre háruló feladatokról szóló 11/2014. (XII. 13.) IM rendelet

A szabadságvesztés, az elzárás, az előzetes letartóztatás és a rendbírság helyébe lépő elzárás végrehajtásának részletes szabályairól szóló 16/2014. (XII. 19.) IM rendelet

Az európai uniós és a nemzetközi bünügyi együttmüködést szabályozó törvények, valamint egyes büntetőjogi tárgyú törvények jogharmonizációs célú módosításáról szóló 2016. évi CIII. törvény 